\title{
ナフィオン膜の電解条件下での安定性に及ぼす圧力の影響
}

\author{
道下 浩征 ${ }^{\mathrm{a}}$, 赤堀 敬一 ${ }^{\mathrm{a}}$, 田中 敬二 ${ }^{\mathrm{a}}$, 松本 広重 ${ }^{\mathrm{a}}$, 春田 大蔵 $\mathrm{b}$, \\ 永田 吉憲 ${ }^{b}$, 山本 壽昭 ${ }^{c}$, 石原 達已 ${ }^{a, *}$ \\ a 九州大学大学院工学研究院 ( \\ b 九州電力株式会社総合研究所（７ 815-8520 福岡市南区塩原 2-1-47) \\ c 株式会社キューキ（广 815-0031 福岡市南区清水4-19-18）
}

\section{Effects of Pressure on Stability of Nafion Membrane under Water Electrolysis}

\author{
Hiroyuki Michishita, ${ }^{a}$ Kei-ichi Akabori, ${ }^{a}$ Keiji Tanaka, ${ }^{a}$ Hiroshi Matsumoto, ${ }^{a}$ \\ Daizou HaruTA, ${ }^{\mathrm{b}}$ Yoshinori Nagata, ${ }^{\mathrm{b}}$ Nagaaki Yamamoto, ${ }^{\mathrm{c}}$ and Tatsumi Ishinara, ${ }^{\mathrm{a}, *}$ \\ ${ }^{a}$ Faculty of Engineering, Kyushu University (744 Motooka Nishi-ku Fukuoka 819-0395, Japan) \\ ${ }^{b}$ Research Center, Kyushu Electric Power Company Limited (2-1-47 Shiobaru Minami-ku Fukuoka 815-8520, Japan) \\ 'Kyuki Company Limited (4-19-18 Shimizu Minami-ku Fukuoka 815-0031, Japan)
}

Received June 18, 2009 ; Accepted November 14, 2009

\begin{abstract}
In previous study, proton conductivity increased with increasing pressure under water electrolysis, so the effects of pressure on the stability of Nafion 117 have been studied. It was found that conductivity of Nafion 117 drastically decreased at initial few $\mathrm{h}$ and then gradually decreased in the following period under electrolysis condition. Decrease in conductivity can be explained by decomposition of Nafion 117. Decomposition of Nafion 117 is accelerated by increasing pressure. Solid state NMR, IR, and Raman spectroscopy suggested that the electrochemical oxidation of sulfo group was occurred at initial period followed by decomposition of CFn main or side chain. Therefore, initial increase in resistance can be explained by desorption of sulfo group in Nafion 117 . Desorption of sulfo group also forms pin hole in Nafion membrane which may cause gas leakage under water electrolysis. Mechanical strength of Nafion membrane is also drastically decreased at initial electrolysis period. Consequently, chemical stability of Nafion 117 may cause serious problem for water electrolysis application and this study reveals that increasing pressure strongly accelerates the decomposition of Nafion 117.
\end{abstract}

Key Words : Nafion 117 Membrane, Stability, Water Electrolysis, Pressure Effects

\section{1 緒 論}

ナフィオン膜は代表的な固体高分子電解質であり, プロト ン伝導型の固体高分子膜型燃料電池や水の電気分解に応用が 検討されているが，安定性が課題となっている．燃料電池に ついてはナフィオン膜の安定性について種々の報告が行われ ている ${ }^{1-5)}$ 。燃料電池への応用においてはナフィオン膜の安 定性の確保は重要な課題であり, 分解挙動の解析とともに, 分解に至る機構についても種々の検討が行われている. 燃料 電池への応用においてはナフィオンの安定性は加湿度の影響 が大きいことが知られているが，別の分解機構として，触媒 層におけるカーボンブラック上の Ptで水の 2 電子還元を生 じ, $\mathrm{H}_{2} \mathrm{O}_{2}$ が生成し， $\mathrm{H}_{2} \mathrm{O}_{2}$ がナフィオン膜の分解に関与する ことも報告されている ${ }^{6-8)}$. 気化した $\mathrm{H}_{2} \mathrm{O}_{2}$ が膜と触媒層間に 拡散し, $\mathrm{Fe}^{2+}$ などの不純物が存在すると $\mathrm{OH}$ ラジカルが生成 し，ナフィオン膜を攻撃する機構でナフィオンは分解するこ とが報告されている ${ }^{3)}$. 一方, 水電解へのナフィオン膜の応 用も行われているが9-11), 水電解条件でのナフィオン膜の分
解挙動に関しては十分な検討は行われていないのが現状であ る. とくに, 加圧下での, ナフィオン膜内に侵入した水によ る分解挙動は検討されていない.

前報では，ナフィオン 117 膜を用いた水の電気分解に及ぼ す加圧の影響を検討した ${ }^{12}$. 加圧は化学平衡的にはエネルギ 一効率に対して負の効果を及ぼすものの, 加圧により電解効 率はむしろ向上し, これは電解質であるナフィオン 117 の伝 導度が向上するためであることを明らかにした，そこで，短 期的には加圧はナフィオン膜を用いる水電解セルの定電流時 のセル電圧の低下という正の効果をもたらした. しかし, こ のような加圧された条件ではナフィオン膜の安定性について 大きな課題があり, 長期的には種々の負の効果をもたらすと 推定される. とくに加圧下ではナフィオン膜は加水分解を受 けやすくなると考えられる。 そこで，本研究ではナフィオン 膜を用いた水電解セルについて, 圧力が長期的な定電流時の セル電圧に及ぼす影響を解明するとともに, ナフィオン 117 の安定性に及ぼす影響の検討を目的とした。 


\section{2 実 験}

実験には，前報で用いたものと同じ電解セルおよび加圧容 器を用いた ${ }^{12}$. 電極としてPt㧍よびPt-Irをそれぞれ，カソ ードおよびアノードに用いた．Pt-Irアノードとして，出発 原料であるテトラアンミン白金 (II) クロリド（1 水和物） $\left[\mathrm{Pt}\left(\mathrm{NH}_{3}\right)_{4} \mathrm{Cl}_{2} \cdot \mathrm{H}_{2} \mathrm{O}\right]$ と塩化イリジウム $\left[\mathrm{IrCl}_{4}\right]$ を $\mathrm{Pt} ： \mathrm{Ir}$ の モル比が $7 ： 3$ になるように水溶液中で混合し，ケッチェン ブラック（三菱化学製，EC600JD）に蒸発乾固により担持し た。金属担持量は $30 \mathrm{wt}$ \% \%とした。カソードには主にPtを用 いた。電極は，アノードと同様に，出発原料に $\mathrm{Pt}\left(\mathrm{NH}_{3}\right)_{4} \mathrm{Cl}_{2}$. $\mathrm{H}_{2} \mathrm{O}$ をケッチェンブラックに対して担持量 $30 \mathrm{wt}$.\%になるよ うに，蒸発乾固した。得られた電極はいずれも $\mathrm{H}_{2}$ 流通下で, $573 \mathrm{~K}$ で還元した。得られた電極はバインダーとして，Pt担 持炭素に対して $10 \mathrm{wt}$ \%\%になるように，ナフィオン 117 パウ ダー $2 \mathrm{wt} . \%$ と $1 \%$ \%ィオン溶液を加えて, 混合, ナフィ オン膜に塗布後 $(20 \mathrm{~mm}$ 角)，ホットプレス（393 K, 2 $\mathrm{MPa}, 10 \mathrm{~min}$ ）した。アノードへの炭素の使用は酸化を生じ る可能性もあるが，電解は室温で，かつセルは水没している ことから，実験を行った 1000 時間程度での電極の見掛けの 大きな変化は認められなかった。集電体としてチタンメッシ ユを用いた。集電体であるチタンメッシュに関して，電極と 接する部分以外は短絡防止のためにエポキシ樹脂でコーティ ングした．電極面積は $2 \mathrm{~cm} \times 2 \mathrm{~cm}$ とした。ナフィオン膜 としてNafion117を使用した。

電解処理や加圧処理がナフィオン膜の安定性へ及ぼす影響 は, 組成変化とイオン交換容量の変化から測定した。ナフィ オン膜の化学的安定性の評価は, $30 \mathrm{MPa}$ で $125 \mathrm{~mA} / \mathrm{cm}^{2}$ で の定電流に扔ける電解を行いながら，所定時間後に高圧容器 内からセルを取り出して分析を行った。また，常圧下でも同 条件で実験を行った。その後, 加圧前後におけるナフィオン 膜のスルホ基，また $\mathrm{CF}_{3}$ 押よび $\mathrm{CF}_{2}$ 基への影響を調べるため に, ナフィオン膜の $\mathrm{F}$ および $\mathrm{S}$ 元素の各電解時間での変化量 を測定した。一方，スルホ基量の定量はICPによりイオン交 換した $\mathrm{Na}^{+}$イオン量を定量して見積もった。実験はナフィオ ン膜を $\mathrm{pH} 12$ 程度の $\mathrm{NaOH}$ に一日浸漬し，スルホ基のプロト ンと $\mathrm{Na}^{+}$をイオン交換させた後，そのナフィオン膜を $\mathrm{HCl}$ に, 再度，一日浸漬して，プロトンと $\mathrm{Na}^{+}$の逆イオン交換をさせ た。その $\mathrm{HCl}$ 中の $\mathrm{Na}^{+}$の濃度を ICP 測定によって定量し，ナ フィオン膜のイオン交換容量の各電解時間での変化を測定し た。また，加圧下および常圧下でのそれぞれの電解時間での ナフィオン膜の引っ張り試験を行い，ナフィオン膜の力学的 強度に及ぼす加圧効果の影響を検討した．力学的評価はす心゙ て室温で行い, 大きさ $2 \mathrm{~cm} \times 1 \mathrm{~cm}$ の材料を引っ張り試験 機（ORIENTEC社製テンシロンRTC-1250）で分析した。ナ フィオン膜の構造変化をさらに詳細に検討するために，固体 NMR 測定を行った. 加圧しながら電解を行ったナフィオン 膜と，加圧なしで電解を行ったナフィオン膜のサンプルを粉 体に切断した．固体NMR 測定はブルッカー社製 AV-400WB を用い，400 MHzで行った。測定はいずれもCPMASS 法に よって行った。フッ素に関してはテフロンを標準物質として, Cに関してはグリシンを標準物質として用い，ケミカルシフ 卜值を決めた。ラマン分光は, 堀場製作所製の LabRAM HR-800を用い，所定時間電解後に大気圧中で測定した。 FTIR 測定は日本分光製IR-660を用いた。

\section{1 電解特性の経時変化}

\section{3 結果と考察}

常圧下, $50 \mathrm{~mA} / \mathrm{cm}^{2}$ での定電流において，100 時間までの 電流電圧特性における経時変化を測定した (Fig. 1)。電解曲 線は電解初期に高電圧側へのシフトが大きく，その後，徐々 に低電圧側にシフトし，IV 曲線の傾きが大きくなった。そ こで, 明らかに電解初期に大きな劣化を生じることがわかる. しかし，電解初期において電圧は向上するものの，数時間以 降，100 時間までは電圧はほとんど変化なく，むしろ電圧は わずかに低減し，内部抵抗は時間とともに減少する傾向があ ることがわかる，そこで，常圧下ではナフィオン膜を用いた 水電解は, 初期の数時間を除くと比較的安定であることがわ かった．数時間以降の内部抵抗の低下する理由については現 在，検討中ではあるが，後に議論するように電解初期にナフ イオン膜が分解し，硫酸やフッ酸が生成することから，これ らのイオンによる水の伝導度の向上が関与するものと推定し ている．伝導度の向上する機構については今後，さらに詳細 に検討する予定である.

次に，加圧がナフィオン膜を用いる水電解セルの安定性に

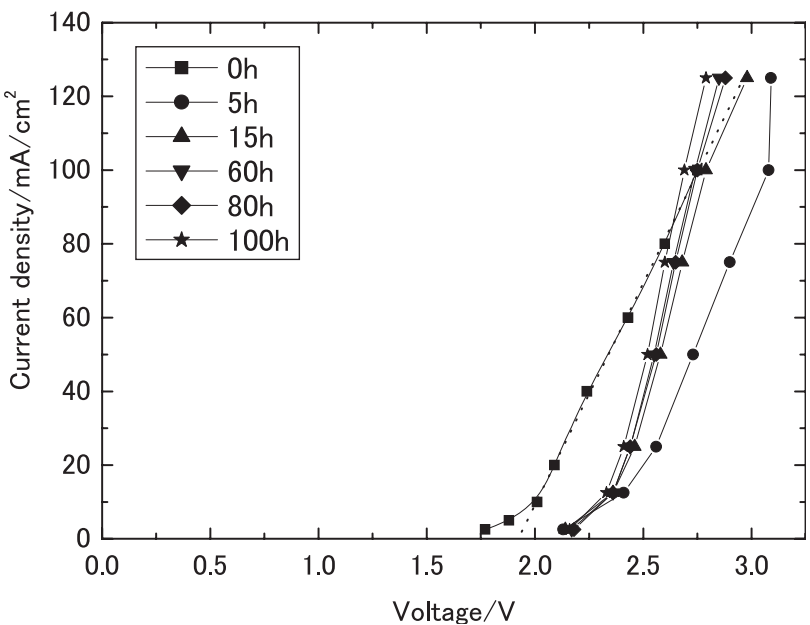

Fig. 1 I-V curve of water electrolysis under atmospheric pressure.

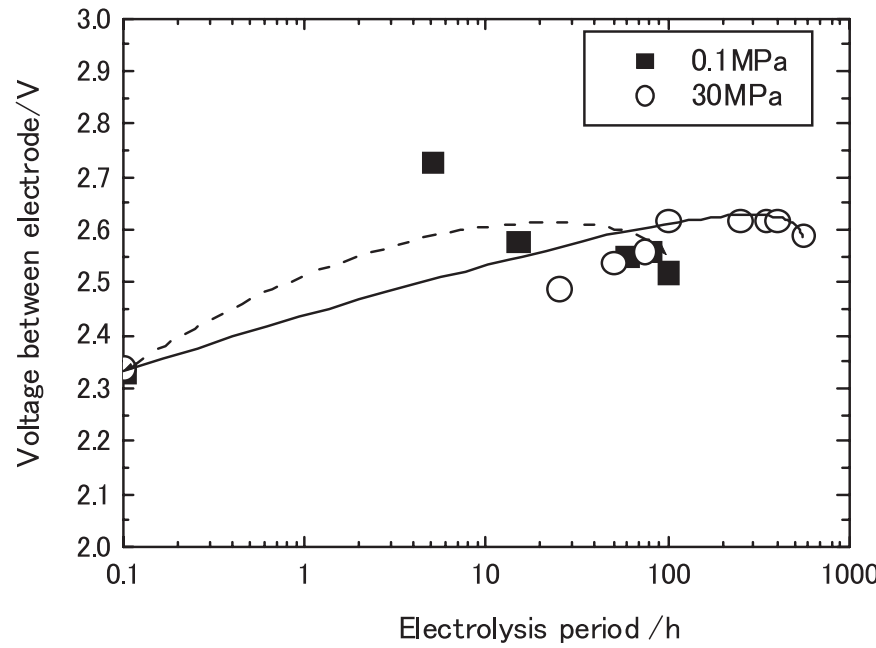

Fig. 2 Potential at $50 \mathrm{~mA} / \mathrm{cm}^{2}$ in water electrolysis as a function of time. 


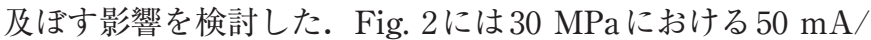
$\mathrm{cm}^{2}$ での定電流電解における電圧の経時変化を示した。図に 示すように加圧下でも，常圧と同様に電解初期に大きな高電 圧側へのシフトが認められるとともに，検討を行った 550 時 間にわたって，電圧は初期で上昇し，その後は大きく変化し ないことがわかった。常圧下の結果と比較すると，加圧によ り $0 \mathrm{~h}$ では，電圧は低下するので，内部抵抗は電解初期には 加圧により低減することがわかる。一方，時間とともに電圧 は増加し，内部抵抗が増加した後，ほぼ変化を示さなくなる ことがわかる．常圧下でのデー夕に比べると加圧下も電圧の 増加は同程度の時間まで生じ，その後の変化は緩やかである ことがわかる，とくに，加圧下では長期にわたり，電解特性 を評価したが， 550 時間にわたって初期に電圧が増加し，そ の後は一定になることがわかった。 そこで，常圧下と同様に， ナフィオン膜による水電解では, 電解初期に扔いて内部抵抗 が大きく増加するとともに，加圧下では長期にわたって，ゆ っくりとセル電圧が増加することがわかった。

加圧下での電解特性における IV 曲線の傾きおよび電圧軸 の切片から求めた見掛けのIR 損および見掛けの電極過電圧

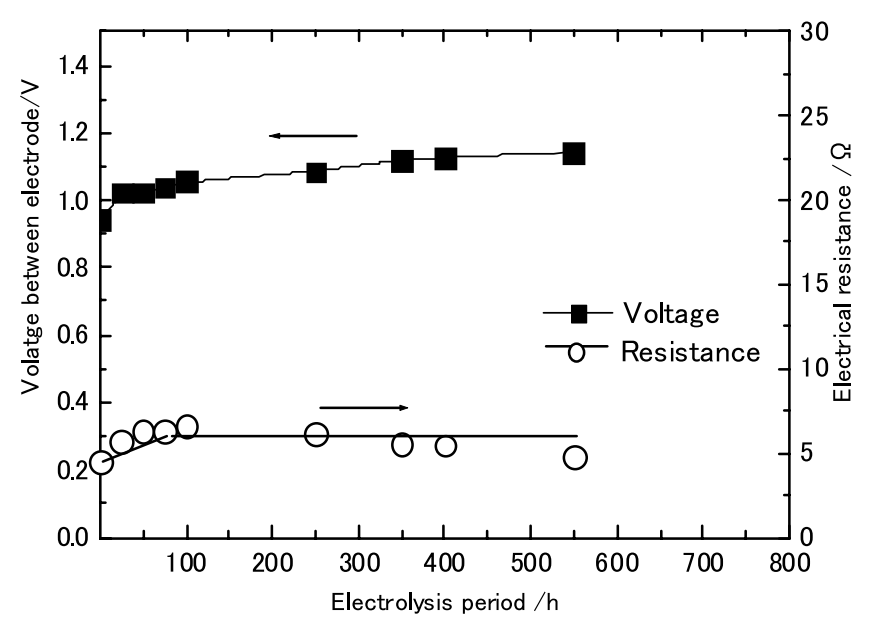

Fig. 3 Overpotential and electric resistance under $30 \mathrm{MPa}$ as a function of electrolysis time.
の経時変化をFig. 3 に示した. 見掛けの電極過電圧 [ここで は最小電解電圧（Fig. 1中に示すように（近似した直線が電 圧軸と交わる電圧 $)$ - (理論電解電圧) で定義) ] は, 電解初 期において大きくなった後，わずかに増加し，550時間にわ たってほぼ1.05〜 $1.10 \mathrm{~V}$ の過電圧を示すことがわかる.つま $\eta$, 電極性能は, 電解に打ける $\mathrm{I}-\mathrm{V}$ 曲線と同様に電解初期 に大きく変化し，電極性能は低下するが，その後は緩やかに 低下し，550時間にわたって，安定であることがわかった． これに対して, IV 曲線の傾きから見積もられるセルの電気 的抵抗は, 電解初期に大きくなった後, 100 時間程度後は電 解時間とともに, 徐々に増加し, その後はほとんど変化しな かった。 そこで, 電解初期には電極過電圧の増加抢よび電気 的な抵抗の増加により, 定電流時の七ル電圧は増加し, その 後のセル電圧の増加は電気的な抵抗の変化により生じるもの と推定される.このようなセル電圧の増加は加圧下において も生じ, 加圧下での電解では, 電解初期にはセル電圧は低下 するが，時間とともにセル電圧はむしろ大きく増加すること がわかる.

\section{2 ナフィオン膜の化学的安定性の評価}

前節で常圧下および30 MPa下のいずれにおいても, 電解 初期にセル電圧は大きく増加した後に, 増加量は少ないなが らも，時間とともに徐々に増加し，とくにこのような劣化は， 常圧下に比べると $30 \mathrm{MPa}$ 下では大きくなることが示された. そこで，このような電気的な抵抗が増加する理由の検討を目 的に，ナイフィオン膜の分解挙動について検討した.

定電流で電解を行った後に，ナフィオン膜をセルより取り 出し, 蛍光 $X$ 線分析により, フッ素およびイオウ濃度の経時 変化を検討し，主鎖およびイオン交換サイトであるスルホ基 量の変化を検討した. Fig. 4には常圧下での電解におけるフ ッ素およびイオウ濃度の経時変化を示した. Fig. 4（a）に示 すように，常圧下においてフッ素濃度は電解時間とともにほ ぼ直線的に減少し， 100 時間後には $1 / 8$ 程度の減少が認めら れた. Fig. 4（b）に示すように，スルホ基を表すと考えられ るイオウの濃度も時間とともに徐々に減少し，100時間後に は $1 / 10$ 程度の減少を生じるがわかった，イオウ濃度の減少 速度は徐々に減少する傾向にあり，60 時間以降はほぼ一定 (a)

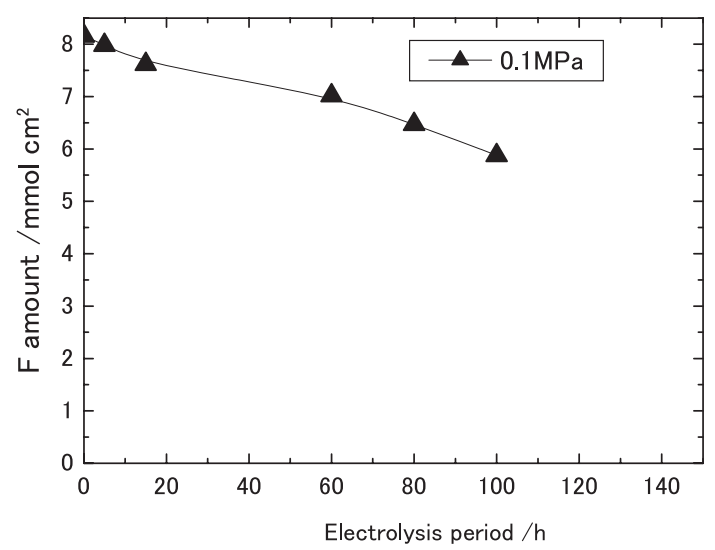

(b)

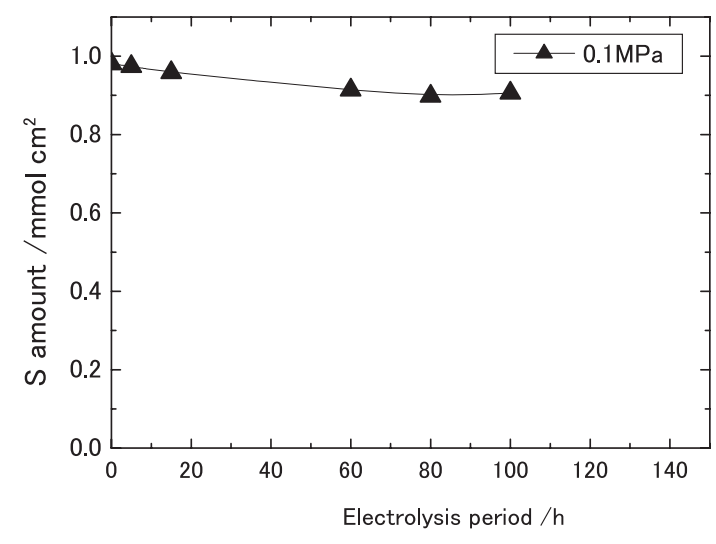

Fig. 4 Fluoride (a) and sulfur (b) content in Nafion membrane as a function of time of electrolysis under atmospheric pressure. 
(a)

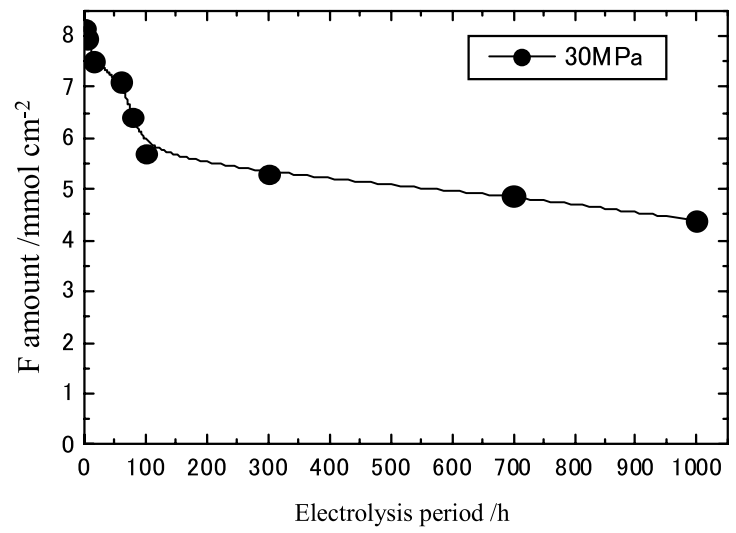

(b)

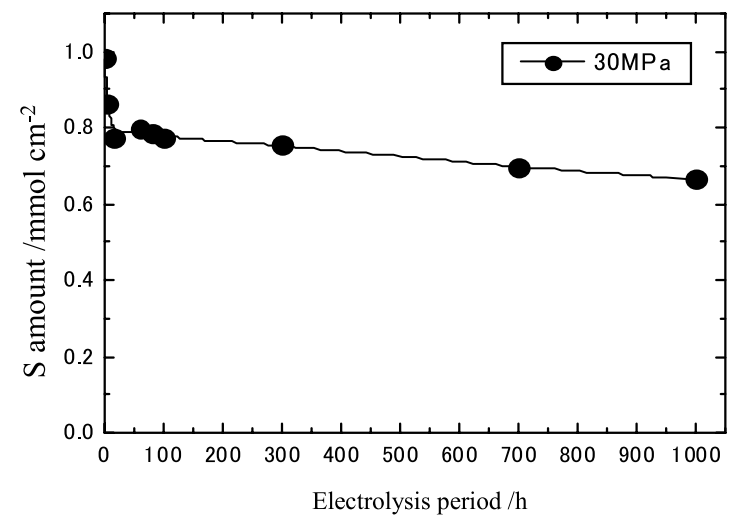

Fig. 5 Fluoride (a) and sulfur (b) content in Nafion membrane as a function of time of electrolysis under $30 \mathrm{MPa}$.

となった。

一方, Fig. 5 には30 MPa下での電解を行った後のナフィ オン膜の組成分析の結果を示した。フッ素濃度とイオウ濃度 の大まかな経時変化は先の常圧下のデータとほぼ同じであっ たが，同じ 100 時間での減少量は常圧下に比べると，30 $\mathrm{MPa}$ 下では大きくなることがわかる。また，常圧下 100 時間 では明確でなかったが，30 MPa下で 1000 時間まで電解を行 ったところ，フッ素掞よびイオウ濃度はともに，1000時間 にわたってゆっくりと減少を続けることがわかった。フッ素 は電解開始後， 100 時間で $1 / 4$ が減少し，イオウは $1 / 5$ 程度 が減少したまた，このようなフッ素とイオウの濃度変化の 経時変化を見ると，分解には比較的，初期に生じる分解と長 期にわたってゆっくりと生じる遅い分解があることがわかる。 このようなナフィオンにおける分解に異なる 2 種類の分解が あることは現在まで，明確に報告されていない。いずれにし ても, 水電解に認められる経時劣化は, 主に電極性能の低減 ではなく, 電解質であるナフィオン膜の劣化挙動と関係して いるものと考えられる．また，劣化量は加圧により大きくな り, 加圧は分解を加速する効果があることがわかる.

\section{3 イオン交換容量の経時変化と加圧効果}

水電解における経時劣化は主に, ナフィオン膜の分解挙動 と関係していることが示唆された。 そこで，ナフィオン膜の イオン交換量を求め, その変化から, ナフィオンのプロトン 伝導度の変化を検討した.ナフィオン膜中のプロトン伝導は 側鎖のスルホ基量と関係しており，前節の元素分析で示され たように，イオウ濃度の低下は $-\mathrm{SO}_{3} \mathrm{H}$ 基の分解による脱離 と考えられる。そこで, $-\mathrm{SO}_{3} \mathrm{H}$ 基量を $\mathrm{Na}$ の逆定量から求め, イオン交換量の経時変化を測定した。

Fig. 6 には常圧下での 100 時間までの電解後のナフィオン 膜のイオン交換容量の変化を示した。大変興味あることに, 電解開始後， 5 時間程度にイオン交換容量は大きく低減した 後に, やや誤差は多いもののイオン交換容量は 100 時間まで はほとんど低下しないという結果になった。初期の減少量は 約 $1 / 4$ 程度であり，これは先に議論した定電流時のセル電圧 の増減の経時変化の傾向およびイオウ濃度の減少挙動とよく 一致している。そこで，明らかなように，電解初期にスルホ 基は分解により大きな濃度減少とそれに伴うプロトン伝導度

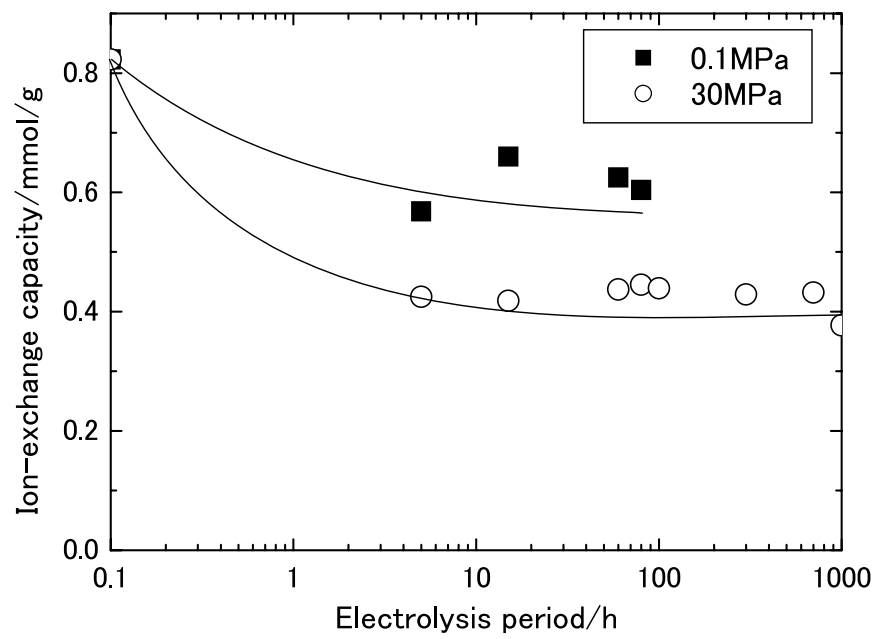

Fig. 6 Ion exchange capacity of Nafion 117 as a function of electrolysis period under atmospheric pressure and $30 \mathrm{MPa}$.

の低減が生じるものと考えられる.

Fig. 6 には30 MPa下でのイオン交換容量の経時変化も併 せて示した. 加圧下での電解によって, ナフィオン膜のイオ ン交換容量は, 電解後, きわめて初期の段階で急激に減少し, その後は 1000 時間にわたって緩やかに減少していることが わかった。 また，常圧下での電解におけるイオン交換容量の 低減量は, $30 \mathrm{MPa}$ における低減量より少なく, 明らかに加 圧はナフィオン膜の分解を加速することがわかる. 現在まで にナフィオンの分解挙動に関しては主に燃料電池の観点で検 討されており, 分解には温度と酸素ラジカルの影響が多いこ とが報告されており，また系に $\mathrm{Fe}$ や $\mathrm{Cu}$ な゙の金属が共存す ると分解が大きく加速することが報告されている13). しかし， 本研究で示すように加圧により, このような大きな分解の促 進効果があることは報告がない. 水電解条件では $\mathrm{H}_{2} \mathrm{O}_{2}$ が少 量であるが, 生成することが報告されており, $\mathrm{H}_{2} \mathrm{O}_{2}$ が生成 すると, 生成した $\mathrm{H}_{2} \mathrm{O}_{2}$ から酸素ラジカルや $\mathrm{OH}$ ラジカルが 生成しやすく, これらのラジカルはナフィオンの側鎖を分解 することから, 本研究でも初期には $\mathrm{H}_{2} \mathrm{O}_{2}$ から生成した酸素 ラジカルか $\mathrm{OH}$ ラジカルによりナフィオンは急速に分解する ものと思われる．加圧下ではナフィオンは膨潤した状態であ 


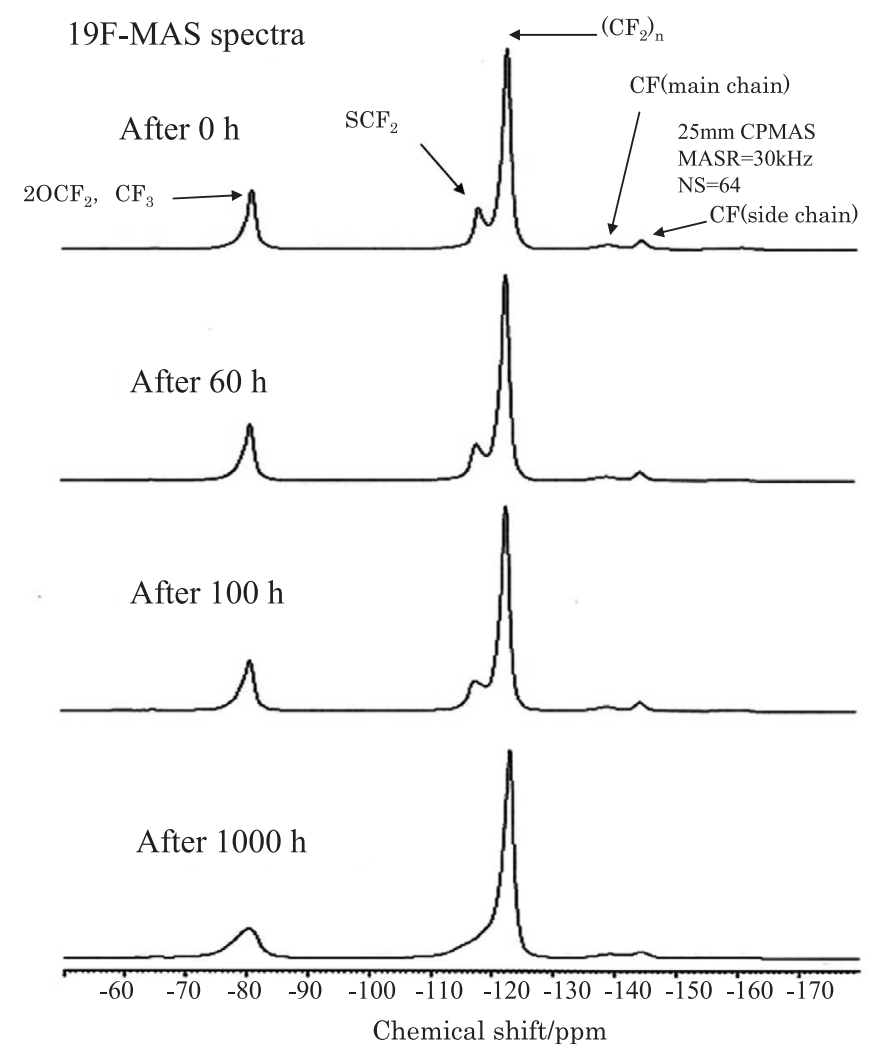

Fig. $7{ }^{19} \mathrm{~F}-\mathrm{CP} / \mathrm{MAS}$ Spectra of nafion membrane after electrolysis at $30 \mathrm{MPa}$.

り，ラジカル種が容易に内部に侵入し易いので，分解は加速 されるものと推定される.

\section{4 ナフィオン膜の分解挙動の解析}

固体 NMRにより，ナフィオン 117 の分解挙動をさらに検 討した. Fig. 7 には， $125 \mathrm{~mA} / \mathrm{cm}^{2} ， 30 \mathrm{MPa}$ で定電流電解後 のセルから取り出したナフィオン膜のフッ素の NMRスペク トルを示す.ナフィオンのフッ素の NMRでは， $-80,-118$, $-120 ，-138 ，-145$ ppmにそれぞれ，4つのピークが観測 され, Chen らの報告 ${ }^{14)}$ からそれぞれ, $2 \mathrm{OCF}_{2}$ と $\mathrm{CF}_{3}, \mathrm{SCF}_{2}$, $\left(\mathrm{CF}_{2}\right)_{\mathrm{n}}, \mathrm{CF}$ (main chain), CF (side chain) に帰属した。 Fig. 7 に示すように，100時間までには各ピークはほとんど 変化することはなく, 主鎖および側差の $\mathrm{CF}_{\mathrm{n}}$ 基は安定に維持 されるものと推定される.一方，1000時間後には明らかに 分岐部分を表すと考えられる OCF および側差の末端を示す と考えられる SCFなどの NMR ピークが減少しており, 主に 側差の $\mathrm{CF}_{\mathrm{n}}$ 基が分解されるものと考えられる。一方，少しわ かりにくいが，側差末端のスルホ基を表すと考えられる SCF に帰属されるNMRピークは 60 時間後にはすでに減少し始め ており，100時間後にはかなり強度が低減することから，末 端のスルホ基の脱離は比較的, 初期から進行するものと推定 された。

次にFig. 8 には ${ }^{13} \mathrm{C}$ の NMRスペクトルを示した。炭素の NMRにも 118，110，104，100 ppmにそれぞれ NMR ピーク が観測され，それぞれをChenらの報告から $2 \mathrm{OCF}_{2}$ と $\mathrm{CF}_{3}$, $\left(\mathrm{CF}_{2}\right)_{\mathrm{n}}, \mathrm{CF}$ (main chain), $\mathrm{CF}$ (side chain) に帰属した ${ }^{14)}$. 炭素の NMR スペクトルも先のフッ素の NMRスペクトルと 同様に，100時間まではほとんど変化はなく，100時間まで は主鎖および側鎖の分解はほとんど進行しないものと推定さ
13C-DDMAS with 19F dec.

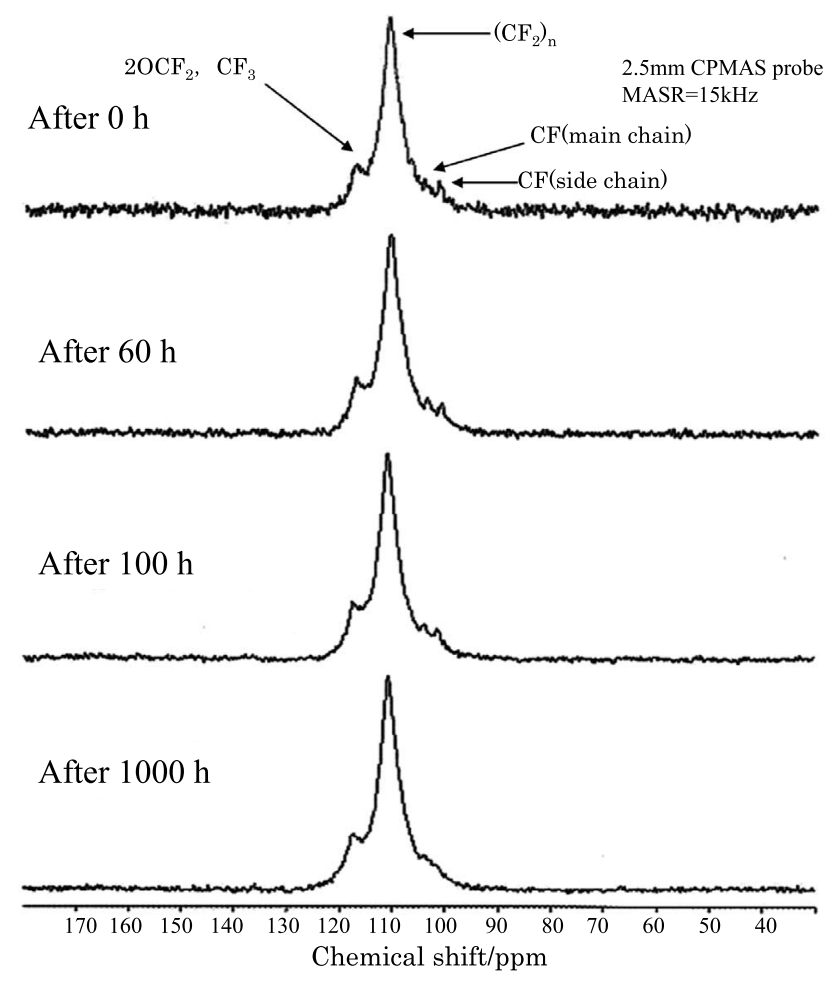

Fig. $8{ }^{13} \mathrm{C}-\mathrm{CP} / \mathrm{MAS}$ Spectra of nafion membrane after electrolysis at $30 \mathrm{MPa}$.

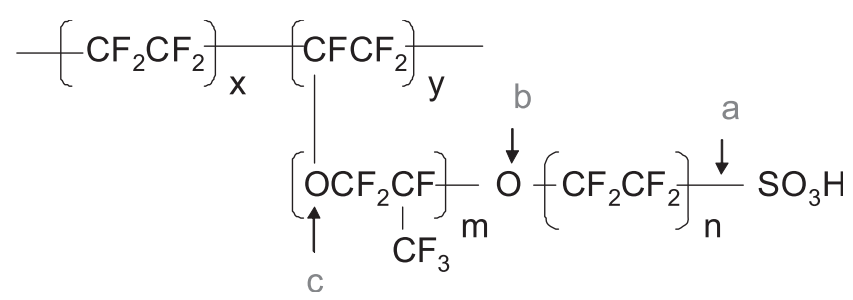

Scheme 1 Molecular structure of Nafion.

れる.一方， 1000 時間後には側鎖の $\mathrm{CF}_{2}$ 基および主鎖の $\mathrm{CF}_{2}$ 基，および分岐鎖部を表すと考えられる $\mathrm{OCF}$ 部の強度が減 少していることから, 主鎖の分解が開始していることがわか る.

Scheme 1 には，ナフィオンの分子構造を示す. NMRの結 果から加圧下での電解によって, 電解初期にはスキーム中 $\mathrm{a}$ で表した側鎖末端のスルホ基が分解により脱離するものと推 定される.これは先に示した電解初期にイオン交換容量が大 きく低減した結果とも一致している，一方，電解時間が長く なると, bまたは $\mathrm{c} て ゙$ 示した側鎖および主鎖の部分での分解 が開始し，構造の崩壊が開始すると推定される.このような 構造の崩壊はゆっくりと進むので, 電気的な抵抗は時間とと もにゆっくりと増加するものと考えられる. 以上より, 定電 流時のセル電圧における初期の大きな増加は主に, ナフィオ ン中のスルホ基の分解によるものであり, その後のゆっくり した分解は側鎖および主鎖の部分での分解によると考えられ る.

一方, ナフィオン膜のスルホ基の分解による生成物は 


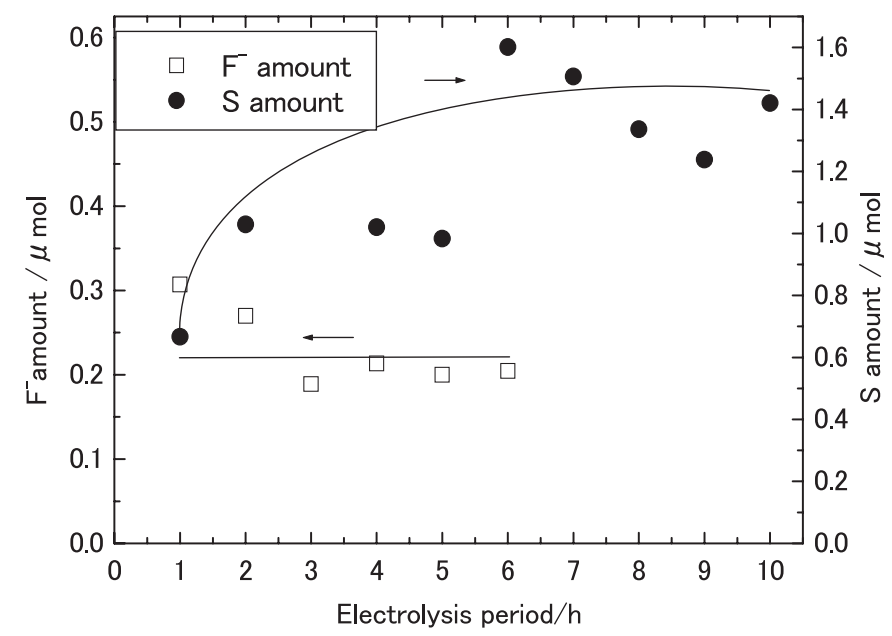

Fig. 9 Fluorine and sulfur concentration in electrolysis water as a function of electrolysis period at $30 \mathrm{MPa}$.

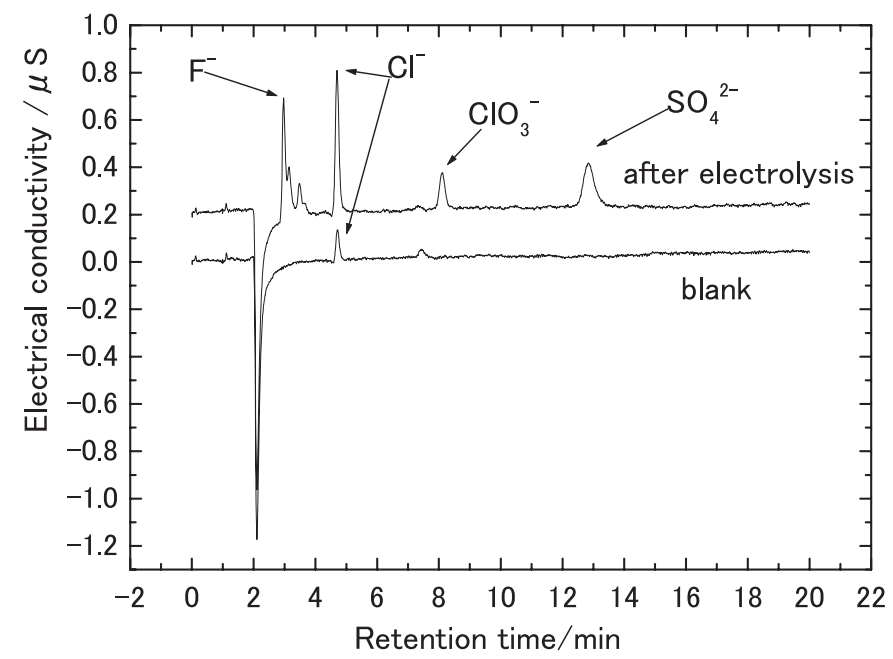

Fig. 10 Ion chromatograph of water, $\mathrm{SO}_{4}{ }^{2-}$ in standard solution, and ion-exchange water after electrolysis at 30 $\mathrm{MPa}$.

$\mathrm{SO}_{4}{ }^{2-}$ と報告されており, 実際に溶液中のフッ素およびイオ ウ成分の経時変化を電解初期について ICPを用いて検討した ところ, Fig. 9 に示すように電解初期にはフッ素濃度はほと んど変化しないのに対し，データにばらつきは多いものの， 電解初期より, 溶液中のイオウ濃度が増加し, フッ素の濃度 変化はほとんど生じないことから, 電解初期で生じる分解は スルホ基の部分であるという NMRでの結果を支持する結果 となっている。一方，スルホ基が分解した際に生じる化合物 は $\mathrm{SO}_{4}{ }^{2-}$ であると報告されており，実際に溶液中の $\mathrm{SO}_{4}{ }^{2-}$ の濃 度をイオンクロマトグラフで, 分析した (Fig. 10).この図 より明らかなように, $\mathrm{SO}_{4}{ }^{2-}$ 生成が認められ, その濃度か ら計算すると, 電解前のスルホ基の約 $1 / 3$ が $\mathrm{SO}_{4}{ }^{2-}$ として生 成することがわかった。 しかし, 生成した $\mathrm{SO}_{4}{ }^{2-}$ 濃度と ICP で求めた溶液中のイオウ濃度は一致せず, ICPで求めたイオ ウの濃度が多かったこと, イオンクロマトでもフッ素イオン が検知できていることから，スルホ基の分解生成物は $\mathrm{SO}_{4}{ }^{2-}$ のみではなく，一部 $\mathrm{CF}_{2}$ を伴った形で生成しているものと推 定される. 一方, このような容量の低下量は先の蛍光 $X$ 線分 析やイオン交換量の減少量とも比較的良く一致しており，電

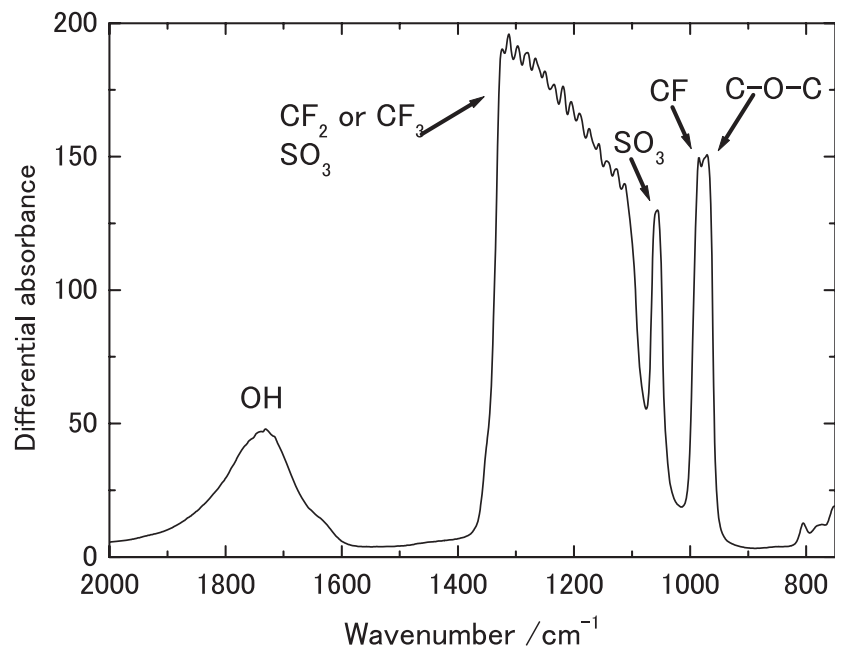

Fig. 11 FT-IR differential spectrum of Nafion 117 membrane before and after electrolysis at $30 \mathrm{MPa}$.

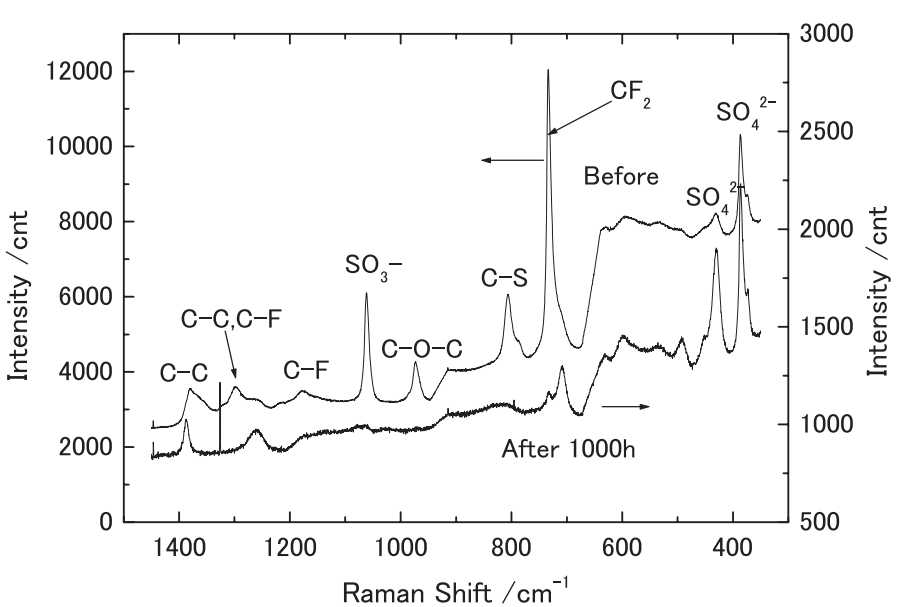

Fig. 12 Raman spectrum of Nafion 117 membrane before and after electrolysis at $30 \mathrm{MPa}$.

解初期に大きなスルホ基量の低下を生じることがわかる.

10 時間程度電解を行った後のナフィオン膜のIR 測定を行 い, 分解前後での差スペクトル（分解後一分解前）を Fig. 11 に示した. Fig. 11 に示すように, 電解前後のIRの差スペ クトルには $1750,1300,1050,980 \mathrm{~cm}^{-1}$ に変化が認められ, それぞれを Tasaka13) らの報告に基づいて $\mathrm{OH}, \mathrm{CF}_{2}$ か $\mathrm{CF}_{3}$ や $\mathrm{SO}_{3}, \mathrm{CF}$ と $-\mathrm{O}-\mathrm{C}$ に帰属した. 図に明らかなようにスルホ基 に対応する $\mathrm{SO}_{3}$ の対称振動およびC-O-C または $\mathrm{CF}_{2}$ の対称振 動に対応する部分に変化が認められており, 先の考察を支持 する結果となった. さらにラマン分光法を使用して, 電解前 後のナフィオン膜の構造変化を分析した. Fig. 12 に, 加圧 下 550 時間電解前後のナフィオン膜のラマンスペクトル示す. ナフィオン膜のラマン分光分析によって, 385, 430, 730, 800，970，1060，1180，1300，1380 cm-1にそれぞれピーク が観測され，Chourdakisらの報告 ${ }^{15)}$ からそれぞれ $\mathrm{SO}_{3}{ }^{-}$, $\mathrm{SO}_{4}{ }^{2-}, \mathrm{CF}_{2}, \mathrm{C}-\mathrm{S}, \mathrm{C}-\mathrm{O}-\mathrm{C}, \mathrm{SO}_{3}-, \mathrm{C}-\mathrm{F}, \mathrm{C}-\mathrm{C}$ たは C-F, C-C に帰属した。電解後のナフィオン膜のラマンスペクトルは電 解前のものと比べ全体的にピーク強度が減少しており, 特に $\mathrm{CF}_{2}$ および $\mathrm{SO}_{3}$-のピークの低下が著しいことがわかり，他の 分析結果とよく一致している. 
$30 \mathrm{MPa} 5 \mathrm{~h}$

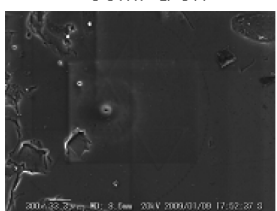

$30 \mathrm{MPa} 300 \mathrm{~h}$

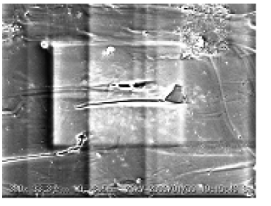

Fig. 13 SEM observation result of Nafion membrane after galvanostatic electrolysis at $30 \mathrm{MPa}$.

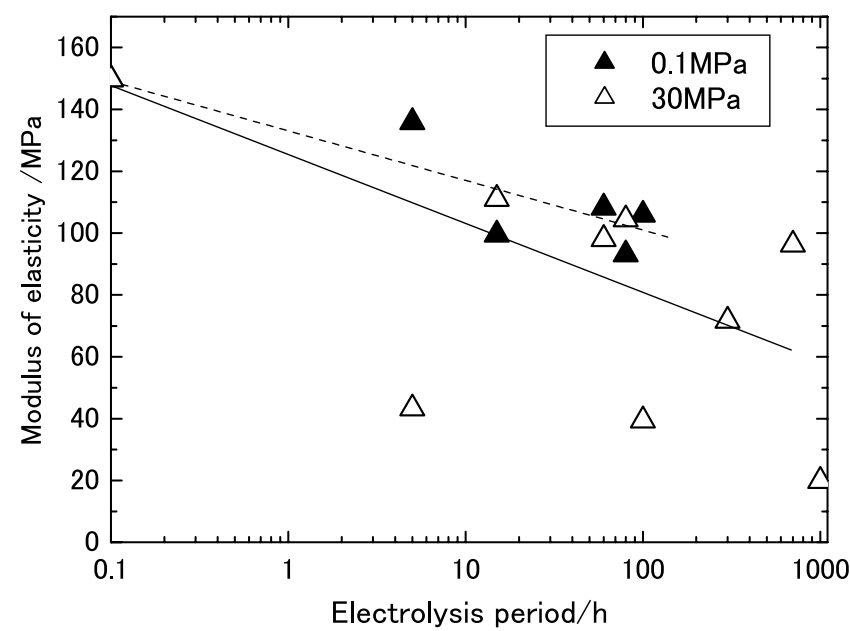

Fig. 14 Mechanical strength of Nafion 117 membrane under galvanostatic electrolysis $\left(125 \mathrm{~mA} / \mathrm{cm}^{2}\right)$ at atmospheric pressure and $30 \mathrm{MPa}$ as a function of period.

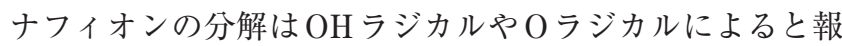
告されており，電解時に生じるこれらのラジカル種が，側鎖 の酸素の部分または末端のスルホ基の部分を切断するものと 考えられる。このような分解は加圧により，より顕著に進む ことから，加圧により，Oラジカルや OH ラジカルが生成し やすくなることと，膜内に水が浸入し，高分子が膨閏した状 態になることから，より容易に生成した $\mathrm{OH}$ または $\mathrm{O}$ ラジカ ルが膜内に侵入し, ナフィオンの分解が促進されるという結 果になったものと考えられる。 そこで，加圧はナフィオンの 伝導度を向上させるものの，加圧により，ナフィオン膜の分 解が促進され, 安定性に大きな負の効果を示すことがわかっ た. 加圧下ではナフィオン膜の電気化学的な酸化が生じやす くなり，耐電圧が低下するものと考えられる.

\section{5 分解挙動が力学的強度に及ぼす影響}

電解により, 常圧および加圧下でのナフィオン膜の分解を 生じることがわかったが, これらの分解挙動は単に電気化学 的な影響を与え，セルの内部抵抗を増加させるのみでなく， 電解質の機械的な強度にも影響を与えると推定される. とく に, Wang らは燃料電池の作動条件でナフィオン膜の分解に より気泡状の亀裂が入ることを報告している ${ }^{16)}$. Wang らの 報告しているボイド状の亀裂が入るのであれば，セルは抵抗
が増加するのみでなく, 電解質膜の機械的な強度の低下を生 じ，水素と酸素のクロスオーバーの可能性がある. SEMに より, 加圧下の電解後のナフィオン膜の形状の変化を観察し た. Fig. 13 に示すように, 電解初期にWang らが報告してい るのと同様のボイド状の亀裂が観測されるとともに, 長時間 電解後にはさらに大きな亀裂の発生が認められ, 表面の凹凸 が顕著になるとともに, 膜にピンホールの発生が生じること がわかった. ナフィオンの分解は単純な電気的影響があるば かりではなく，電解により，膜にピンホールが発生するので, 水電解では生成した酸素中への水素の混入や水素中への酸素 の混入などのクロスオーバーの問題を生じることが予想され る.このようなピンホールの発生は水電解により生成した $\mathrm{SO}_{4}{ }^{2-}$ が, 溶出する際に発生するものであり, 比較的, 電解 の初期より発生することがわかった。

次に,このようなピンホールがナフィオン膜の機械的な強 度に及ぼす影響を検討した. Fig. 14 には常圧下での所定時 間電解後のナフィオン膜の機械的強度の電解時間依存性を示 した。 サンプル数が少なく，測定点数が各点で一点であり， 機械的強度の評価としては信頼性に劣り, かつ, データのば らつきは大きいものの, 電解初期において大きな機械的強度 の低下を生じることがわかり, 前節で述べた分解挙動におけ る電気的性質の変化によく似た時間依存性を示した。一方, Fig. 14 中には30 MPaで電解を行った後の, ナフィオン膜の 機械的強度の経時変化も示した. Fig. 14 の常圧下での結果 と比べると, 傾向はよく似ており, 電解初期の 100 時間で機 械的強度が大きく低下した後に，機械的強度は時間とともに， 徐々に低下することがわかった。このようなナフィオン膜の 機械的な強度の低下は, 電解により発生したボイド状の亀裂 に起因するものであり, 初期において大きく強度が低下する ことから, 電解初期で起こるスルホ基の分解がおもに亀裂を 発生するものと推定している. 一方, その後に生じる主鎖お よび側鎖の分解は機械的強度には顕著な影響は及ぼさず，機 械的強度はゆっくりと低下することがわかった。 また, 常圧 下に比べると, 加圧による強度低下は大きく, これも加圧下 での分解が促進される結果とよく一致している．以上より， 電解に伴うナフィオン膜の分解は機械的強度の低下やピンホ ールの発生により，七ルの信頼性を大きく低下させることが わかった。

\section{4 結 言}

定電流下でのナフィオン膜を用いたセルでの電解を行い, ナフィオン膜の安定性について以下の結果を得た.

1 ）ナフィオン 117 は, 加圧により, 初期伝導度は増加する が，水電解条件ではスルホ基の酸化や側鎖の加水分解が 進行しやすく, 定電流時のセル電圧は時間とともに増加 した. とくに初期の 100 時間以内の劣化が著しいことが わかった。 これは電極特性の低減とともに, 電解質の抵 抗損が大きくなるために生じることがわかった。このよ うなセル電圧の増加は加圧下の方が著しく, 加圧は長期 的な安定性に大きな課題があると推定される.

2 ）ナフィオン 117 の水電解下での分解には 2 つ分解機構 があり，初期に生じる $\mathrm{SO}_{3}{ }^{2-}$ の酸化的分解と考えられる 早い分解と, $\mathrm{H}_{2} \mathrm{O}_{2}$ などから発生すると考えられるラジ カルによる主鎖および側鎖の分解がゆっくり進行する遅 い分解があることがわかった.

3 ）スルホ基の分解により, ボイド状亀裂が発生することか 
ら，ナフィオンの機械的強度の低下が生じることがわか った.とくに力学的強度は 1000 時間後には初期の半分 程度まで低下した。

4 ) 電解条件で発生するボイド状亀裂はナフィオン膜にピン ホールを形成する危険が高く，ナフィオン膜を用いる水 電解セルではこのような膜の分解による水素と酸素のク ロスオーバーの危険性があることが示唆された。

5 ）高分子水電解は，高効率な電解技術ではあるが，今後， 加圧下で用いるには高分子電解質の安定性の向上を図る 必要がある。

\section{文 献}

1) M. Aoki, H. Uchida, and M. Watanabe, Electrochem. Comm., 8, 1509 (2006).

2) O. A. Baturina, S. R. Aubuchon, and K. J. Wynne, Chem. Mat., 18, 1948 (2006).

3) M. Aoki, H. Uchida, and M. Watanabe, Electrochem. Comm., 7, 1434 (2005).

4) C. G. Huang, K. S. Tan, J. Lin, and K. L. Tan, Chem. Phys. Lett., 371, 80 (2003).

5) S. Mathias, M. Lorenz, N. Wagner, and E. Gulzow, Fresenius' J. Anal. Chem., 365, 106 (1999).

6) A. G. Guzman-Gracia, P. N. Pintauro, M. W. Verbrugge, and E. W. Schneider, J. Appl. Electrochem., 22, 204
(1992).

7) H. Wang and G. A. Capuano, J. Electrochem. Soc., 145, 780 (1998).

8) M. Inaba, T. Kibumoto, H. Yamada, A. Tasaka, Y. Iriyama, T. Abe, and Z. Ogumi, in Proc. 10th FCDIC Fuel Cell Symposium, Tokyo, Japan, 13-14 May, 2003, p. 261.

9) Y. Zhang, C. Wang, N. Wan, Z. Liu, and Z. Mao, Electrochem. Comm., 9, 667 (2007).

10) A. Marshall, B. Borresen, G. Hagen, M. Tsypkin, and R. Tunold, Energy, 32, 431 (2007).

11) V. Antonucci, A. Di Blasi, V. Baglio, R. Ornelas, F. Matteucci, J. Ledesma-Garcia, L. G. Arriaga, and A. S. Arico, Electrochim. Acta, 53, 7350 (2008).

12) H. Michishita, H. Matsumoto, and T. Ishihara, Electrochemistry, 76, 288 (2008).

13) T. Kinumoto, M. Inaba, Y. Nakayama, K. Ogata, R. Umebayashi, A. Tasaka, Y. Iriyama, T. Abe, and Z. Ogumi, J. Power Sources, 158, 1222 (2006).

14) Q. Chen and K. Schmidt-Rohr, Macromolecules, 37, 5995 (2004).

15) N. Chourdakis and G. A. Voyiatzis, J. polym. Sci. Part B, Polymer physics, 45, 2509 (2007).

16) F. Wang, H. Tang, M. Pan, and D. Li, Int. J. Hydrogen Energy, 33, 2283 (2008). 